\title{
Lifelong learning as cruel optimism: Considering the discourses of lifelong learning and techno-solutionism in South African education
}

\author{
Sara Black ${ }^{1}$ (D) \\ Accepted: 14 October 2021 / Published online: 28 October 2021 \\ (c) UNESCO Institute for Lifelong Learning and Springer Nature B.V. 2021
}

\begin{abstract}
This article seeks to examine how two discourses -of lifelong learning and technosolutionism - tangle with each other in South African education policy imaginaries, particularly the latter discourse as a response to an (arguably manufactured) frame of "crisis". The author suggests that the discourse of lifelong learning constructs a relation of what Lauren Berlant terms "cruel optimism" for the marginalised majority of South Africans, sustaining a fantasy of liberatory education despite empirical evidence to the contrary. First, the prevalence of this discourse in key policy texts (predominantly education policy white papers) is examined, along with how both instrumentalist and humanist framings of lifelong learning promote and sustain this relation in spite of the ordinariness of the "attrition of the subject" (in Berlant's terms) as a defining experience of everyday life. Next, the ubiquitous frame of crisis in education analysis in South Africa is considered, along with techno-solutionism (a term coined by Evgeny Morozov in 2013) as a popular response amongst the dominant middle-class minority. The article suggests that cruel optimism is sustained for this middle-class group through techno-solutionist education utopias, as what Berlant terms a "redefinitional strategy" for manufacturing ahistorical moments of agency in the face of persistent structural issues centuries in the making. The lens of cruel optimism is thus offered as a mechanism for denaturalising the political work of both discourses, a necessary (albeit insufficient) move towards better grasping the nature of South African education concerns, as well as theories of change that might offer genuinely emancipatory learning for all.
\end{abstract}

Keywords Lifelong learning · Crisis · Cruel optimism · Techno-solutionism · Policy discourse $\cdot$ South Africa

Sara Black

sara.black.za@gmail.com

1 Centre for Education Rights and Transformation, University of Johannesburg, Johannesburg,

South Africa 


\section{Résumé}

Apprentissage tout au long de la vie, un « optimisme cruel » : les discours de l'apprentissage tout au long de la vie et du techno-solutionnisme dans l'éducation sud-africaine - L'auteure de cet article tente d'analyser comment deux discours - celui de l'apprentissage tout au long de la vie et celui du solutionnisme technologique - s'entremêlent dans l'imaginaire des politiques éducatives sud-africaines, en particulier le dernier discours en réaction à un cadre de « crise » (vraisemblablement fabriqué). L'auteure avance que le discours de l'apprentissage tout au long de la vie construit une relation de ce que Lauren Berlant appelle « optimisme cruel » pour la majorité marginalisée des Sud-Africains, qui entretient un fantasme d'éducation libératrice malgré les preuves empiriques du contraire. Elle explore dans un premier temps la prévalence de ce discours dans les principaux textes directifs (principalement les livres blancs sur les politiques éducatives), ainsi que la manière dont les encadrements instrumentalistes et humanistes de l'apprentissage tout au long de la vie favorisent et entretiennent cette relation, malgré la banalité de « l'usure du sujet » (expression de Berlant), qui est une expérience déterminante du quotidien. Elle aborde ensuite le cadre de crise omniprésent dans l'analyse de l'éducation en Afrique du Sud, ainsi que le techno-solutionnisme (terme créé par Evgeny Morozov en 2013) en tant que réponse populaire parmi la minorité dominante de la classe moyenne. L'auteure signale que l'optimisme cruel est favorisé au sein de ce groupe par les utopies éducatives techno-solutionnistes, et par ce que Berlant appelle "stratégie de redéfinition » visant à fabriquer des éléments ahistoriques d'agentivité face aux problèmes structurels persistants dans les siècles à venir. L'optique de l'optimisme cruel est donc proposée comme mécanisme censé dénaturaliser l'action politique des deux discours, mouvement nécessaire (bien qu'insuffisant) pour mieux saisir la nature des préoccupations éducatives sud-africaines, ainsi que les théories du changement susceptibles d'apporter un apprentissage véritablement émancipateur pour tous.

\section{Introduction}

Being critical of "lifelong learning" or technological "advancement", superficially, seems destined to invite commonsense scorn - what possible objections could any reasonable person have to continuing these most human pursuits? But - as other scholars have already noted (cf. Biesta 2006; Lee and Friedrich 2011; Elfert 2015, 2018) - the term lifelong learning has a long history and its meaning is far from fixed, uncontested or neutral. The assumption of technology as intrinsically good also does not withstand scrutiny (Bridle 2019; Morozov 2013), despite widespread belief to the contrary.

This article seeks to examine how these two discourses - lifelong learning and techno-solutionism - tangle with each other in South African education policy imaginaries, particularly the latter discourse as a response to an (arguably manufactured) frame of "crisis". I question how these ideals relate to ordinary South Africans' investment in the formal, credentialled education currently available to them, since belief in formal education as liberatory and adequate for upward social and 
economic mobility is still prevalent, despite the system failing to deliver on this promise for the vast majority of the population since the advent of democracy 27 years ago.

I begin by considering the appearance of the discourse of lifelong learning in South African policy, its relation to the international Faure (Faure et al. 1972) and Delors (Delors et al. 1996) reports, and the rise of human capital and human resource development framings regarding the role of education in repairing past inequities and schisms in South Africa's emerging democracy after 1994. I then argue that the contradictions that appear between humanist (social democratic) ideals and instrumentalist (human capital) framings are not antagonistic, but rather coconstructive of a relation of attachment to formal state-sanctioned education as a means to obtaining "a better life", and deploy Lauren Berlant's concept of "cruel optimism" (Berlant 2011) to suggest how this attachment is sustained in the face of empirical evidence to the contrary.

Finally, this article examines the turn to technology in education ("edtech") discourses as a popular remedy to the crisis of education provision in the country. Adopting the mantles of emancipation and efficiency simultaneously, technological foci in South African education (both as objects of study and modes of delivery) abound. I suggest that a discursive type of techno-solutionism (Morozov 2013) is present, and that this discourse works to sustain attachment to formal education as a vehicle for economic development and social cohesion. However, techno-solutionist utopias are only a remedy in the imaginaries of activists and middle-class analysts, who construct a sense of crisis where the vast majority of South Africans experience an interminable "ordinariness" in education's broken promises (Berlant 2011). That is: techno-solutionism sustains investment in educational improvement, but only for the hegemonic minority wedded to the fantasy of middle-class education for all without radical shifts in political-economic arrangements at the macro level.

This article concludes by suggesting that cruel optimism is a useful lens for denaturalising hegemonic discourses such as lifelong learning (both its humanist and instrumentalist forms) and techno-solutionism as elitist imaginaries that do not relate to the ordinary experiences of the vast majority of South Africans.

\section{Lifelong learning and its various guises}

The point of departure for this discussion is the tension between what might be termed instrumentalist approaches (often referred to as "human capital theory" or "neoliberal") and humanist approaches (also framed as "social democratic" or "progressive") underpinning the concept of lifelong learning as it has been taken up in education policy. While discussed at length elsewhere (cf. Lee and Friedrich 2011), the former can be summarised as "lifelong learning to constantly upgrade existing and accumulate new skills so as to stay relevant in a competitive, capitalist labour market", while the latter might be summarised as "lifelong learning to continue pursuing deeper understandings of human experience, both individually and collectively, towards ends that include social justice, joy, democratic participation and flourishing". Rarely do education policy texts include only one of these ideals; 
nor are the contradictions between them explicitly explored by policies themselves (e.g. via radical framings of education practices which question whether flourishing and genuine democracy is possible under capitalist labour market conditions; see Vally and Motala 2014). Rather, policy texts tend to present a bricolage of differing discourses (Ball 1993, 2015), offering empty/floating signifiers shared by both discourses (e.g. terms such as "quality" - see Biesta 2004) and allowing readers to project or assume their preferred interpretation.

UNESCO's Learning to Be report (the "Faure report") (Faure et al. 1972) offered a vision for education and its role in human society primarily premised on an ideology of human flourishing and emancipatory development (Elfert 2015, 2018; Friedrich and Lee 2011), at times even making small allowance for more radical framings of education that pushed back against prevailing capitalist forms of political economy (Lee and Friedrich 2011). The subsequent "Delors report" (Delors et al. 1996) - despite being published in the mid-1990s during the heyday of neoliberal thinking just as UNESCO was under significant pressure from both the Thatcher (United Kingdom) and Reagan (United States) administrations (Elfert 2018) - held out for progressive ideals of humanity beyond homo economicus (ibid.), even if more radical critiques of capitalist political economy were quietly elided (Lee and Friedrich 2011).

However, despite UNESCO's attempted discursive stand through these reports against the onward march of globalisation and neoliberalist thinking, the take-up of lifelong learning ${ }^{1}$ has tended towards instrumentalism (Biesta 2006, 2013), with a focus on labour market return:

Lifelong learning discourses are currently the overarching educational and training policy discourses ... [i]n their more than 40 years of existence, most of these discourses have come to reflect our technocratic global conditions more and more, emphasizing the pursuit of self-interest as freedom and objectifying most people into the assets of the few (Friedrich and Lee 2011, p. 154).

Post-democratic South African education policy has not escaped these transnational forces and trends, including the global discourse of lifelong learning.

\section{Lifelong learning in South African education policy}

South Africa as a newly democratic nation-state emerged from international isolation in 1994 just as globalisation and neoliberal approaches to international and national finance and governance were in ascendency. Incoming democratic policymakers picked up the international discourse of lifelong learning immediately, with the term present in policy white papers since 1995 up until the present day. ${ }^{2}$ These

\footnotetext{
1 The slip from lifelong education to lifelong learning has also been described as suggesting a narrowing of education imagination towards technicist ideals - see the section on techno-solutionism below.

2 One instance of the term lifelong education occurs in the 1995 White Paper on Education and Training (DoE 1995), with all subsequent instances using the term learning - more on the distinction this shift signals can be found later in this article.
} 
tone-setting documents exhibit the same dual nature of placing human capital instrumentalism alongside progressive ideals of maximising human potential. The following four extracts are all from the White Paper on Education and Training (DoE 1995), a policy document still broadly seen as setting the tone for the then newly elected government's approach:

Chapter 2, Clause 8: “... the emerging consensus on the importance of lifelong learning as the organising principle of a national human resource development strategy ..."

Chapter 2, Clause 9: "The concept of lifelong learning organised in terms of a National Qualification Framework, is incorporated in the human resource development strategy of the government's Reconstruction and Development Programme."

Chapter 4, Clause 5: "The over-arching goal of policy must be to enable all individuals to value, have access to, and succeed in lifelong education and training of good quality...."

Chapter 4, Clause 13: "The realisation of democracy, liberty, equality, justice and peace are necessary conditions for the full pursuit and enjoyment of lifelong learning. ..." (DoE 1995; emphases added).

These extracts represent the deployment of the concept of lifelong learning in somewhat contradictory ways. This use continues from the core White Paper of 1995, through the White Paper on Higher Education (DoE 1997), the White Paper on Further Education and Training (DoE 1998) and the White Paper for Post-School Education and Training (DHET 2013). In each, lifelong learning is simultaneously cast as a route to human fulfilment as well as a necessary habit of an employable member of the national workforce. The incoming African National Congress (ANC)-led government needed to accommodate an imagination of education which was not only humanising and democratic but at the same time also offered skills to access forms of industrial activity previously ruled by the "colour bar". Incorporating both discourses (labour-market skills and democratic humanism) was a necessary strategic move both to address the lack of legitimacy of public (state) education created by the Nationalists and their system of Bantu education ${ }^{3}$ (which was most keenly demonstrated by the 1976 student uprisings), and to break away from the tactical position taken up by anti-apartheid struggle activists of "Liberation Before Education".

However, as South Africa emerged from isolation in the mid-1990s, with the global currents of that time, the delicate balance between these two imperatives swung immediately in favour of a neoliberal bias (Fiske and Ladd 2004; Christie 2008). Lifelong learning in policy documents was increasingly framed in

\footnotetext{
3 The 1953 Bantu Education Act (Union of South Africa 1953) and its subsequent amendments were the primary policy apparatus of the South African Apartheid state, whereby different education systems were set up based on race. These policies differentiated education provision by location, funding, curriculum and language, and fomented significant social unrest. The legacy of "Bantu Education" still persists in South African public education today.
} 
labour-market and human resource development terms, with a neoliberal framing of students as individually responsible for their own successes (Silbert 2012).

South Africa exhibits shockingly low education attainment by any measure: less than half who undertake the final National Senior Certificate (the school leaving/exit qualification) qualify to move on to tertiary education (M\&G 2020). The vast majority of students who fail are poor, and youth unemployment levels are soaring (Stats SA 2020), while the government doubles down on supplyside labour market interventions despite a deindustrialised formal economy that exhibits low job growth (Vally and Motala 2014; Allais 2020). And yet, the platitudes of "work hard to make it" and "become a lifelong learner to get a dream job" are ubiquitous in South Africa. In the face of such overwhelming evidence to the contrary, why do poor and marginalised South Africans still subscribe to such ideals? In the next section, I explore the concept of "cruel optimism" (Berlant 2011) as a potential explanation.

\section{Cruel optimism}

Why do people stay attached to conventional good-life fantasies - say, of enduring reciprocity in couples, families, political systems, institutions, markets, and at work - when the evidence of their instability, fragility, and dear cost abounds? Fantasy is the means by which people hoard idealizing theories and tableaux about how they and the world "add up to something" (Berlant 2011, p. 2).

Berlant's concept of cruel optimism explores what she terms collective affect - that is, the role of desire and fantasy in our collective political relations with each other and with the institutions that govern our lives. For Berlant, optimism is not a feeling or emotion of happiness, but a willingness to attach, to invest. Optimism might even manifest in banal stability, in the absence of loss; that is, the belief that the things we enjoy or desire will not disappear. An optimistic attachment becomes cruel when

the object/scene that ignites a sense of possibility actually makes it impossible to attain the expansive transformation for which a person or a people risks striving (ibid., p. 2).

Berlant's approach offers a language of description that not only explains complicity in structures and activities that are flagrantly not in people's interests, but also a relation between the material and the psychosocial through affect.

That South Africans' unfulfilled expectations of the promise of emancipatory education do not disintegrate into anomie or anarchy may be somewhat due to a cruelly optimistic attachment, and the "ordinariness of suffering" for the many. Viewed through the lens of cruel optimism, a dialectic between the discursive and the affective sustains and reproduces investment in the idea of education as emancipatory, outside of empirically informed rational calculations of the odds of success in an obviously distorted system. 


\section{Cruel optimism and lifelong learning}

I would argue, however, that there is also a connection between sustaining a relation of cruel optimism to education - at least in the South African case - and the ideal of lifelong learning as it manifests in both its humanist and neoliberal guises. This happens at two levels: the first relates to the compatibility of lifelong learning as an ideal and the slow "attrition of the subject" (Berlant 2011) as normalised in everyday South African life-making for the poor; the second is in how the presence of both discourses (instrumentalist and humanist) serves to suppress questioning of the optimistic attachment to education.

\section{"Slow death" - attrition and suffering as a state of ordinariness}

Berlant suggests that one mechanism of examining a cruelly optimistic relation is what she terms "slow death":

slow death refers to the physical wearing out of a population in a way that points to its deterioration as a defining condition of its experience and historical existence (Berlant 2011, p. 95; italics in original).

Slow death is, in essence, the attrition or wearing down of the subject as a normalised state of being. Processes of everyday life-making and life-building gently erode not just the (normative) agency of the subject, but the subject itself. What might appear as a crisis to an external analyst presents as just everyday life to those who live it:

being treads water; mainly, it does not drown. Even those whom you would think of as defeated are living beings figuring out how to stay attached to life from within it, and to protect what optimism they have for that, at least (Berlant 2011, p. 10; emphasis added). ${ }^{4}$

The slow attrition of the subject seems an implicit premise for the concept of lifelong learning. Whether constantly acquiring skills for work or striving for deeper humanity, lifelong learning (particularly when interpreted individualistically - see Biesta 2006, 2013) suggests that just being is to backslide; one must always be producing, or becoming better, in order to be "fully human". For the vast majority of South Africans, denied their full humanity for so long, lifelong learning as a means to becoming fully human (however imagined) may seem a contrapositive framing of their ordinary everyday lived experience; if to be human is to constantly (formally) learn, then experiencing persistent structural barriers to formal learning (made personal through neoliberal discourses of individualisation) makes one feel less than human.

\footnotetext{
${ }^{4}$ Far from being a deficit framing of those for whom suffering is banal and ordinary, such a description suggests that there is a tenacity for "staying attached" to what remains (a disposition often over-individualised and used as a "poster child" for agency through a neoliberal framing of "resilience" and "grit").
} 
But while the two interpretations of lifelong learning (instrumentalist and humanist) have been posited as distinct (Lee and Friedrich 2011) or even outright irreconcilable (Griffin 2010), ${ }^{5}$ I suggest both are necessary for the discursive maintenance of a relation of cruel optimism to education, a type of "good cop/bad cop" arrangement that switches "process" for "telos" as need arises. Should the value of education as fulfilling in and of itself be questioned in a moment of alienation or frustration, the instrumentalist rationale suggests that learning need not be pleasant to (eventually) offer economic return. Should the rate of economic return for invested effort be questioned, then the humanist rationale steps in to posit education as intrinsically worthwhile and beyond mere commodification. Either way, questioning the promise of the attachment is responded to with a "bait-and-switch" between each discourse.

This necessarily dual definition of education is present in the Delors report, which states that "[n]ot only must it adapt to changes in the nature of work, but it must also constitute a continuous process of forming whole human beings" (Delors et al. 1996, p. 21), a position Moosung Lee and Tom Friedrich (2011) describe as "well grounded in social democratic liberalism yet compatible with the rule of capital" (ibid. p. 161). That both transnational and national discourse-setting documents seem unable to dispense with either framing suggests more than just competing narratives, but potentially an unholy alliance between the two in manufacturing legitimacy despite organised education's increasing difficulty in offering either economic satisfaction or democratic humanism to the most marginalised of the world.

Thus, not only does the ordinariness of slow death trouble the analyst's prognosis of crisis regarding the majority of South Africans' experience of formal education, but what scant dissent does arise is quashed by the double-discourse present not just in policy documents, but also broader imaginations influenced by their social visions. Berlant writes:

[S]ometimes, the cruelty of an optimistic attachment is more easily perceived by an analyst who observes the cost of someone's or some group's attachment to $\mathrm{x}$, since often persons and communities focus on some aspects of their relation to an object/world while disregarding others. But if the cruelty of an attachment is experienced by someone/some group, even in a subtle fashion, the fear is that the loss of the promising object/scene itself will defeat the capacity to have any hope about anything (Berlant 2011, p. 24; emphasis added).

That learning is a permanent state - a lifelong endeavour - enables both these mechanisms in a way that a finite education would struggle to do. Framing learning as lifelong generates a sort of temporal education asymptote - an inability to arrive at either a place of "being educated" or of economic sufficiency ... the fantasy is always put off until tomorrow. Neither the normalisation of being perpetually not educated nor the double nature of education activity as both modus operandi

\footnotetext{
5 These discourses are contradictory in practical, material terms, but at the level of representations they make for oddly common bedfellows.
} 
(process) and opus operatum (product) is as effective unless the actual conception of education itself is interminable, a phenomenon Gert Biesta (2013) refers to as the "politics of learning".

\section{Commitment to sustaining the attachment}

The South African Open Learning Policy Framework (OLPF), circulated in draft form in $2017,{ }^{6}$ opens as follows:

The Minister of Higher Education and Training, Dr BE Nzimande, MP has repeatedly affirmed that employment is essential for creating social stability in South Africa. People who do not have a reasonable hope of finding decent work - or creating their own sustainable livelihoods - have little to lose and have little stake in maintaining a stable society (DHET 2017, p. 1).

Opening with normative assertions about employment indicates the dominance of instrumentalism at this point in policy discourse. Indeed, the majority of texts regarding education's systemic health or failure since the National Development Plan (RSA 2012) invoke the "triple cocktail" of inequality, poverty and unemployment as the primary concern of education organisation and interventions, with education failure in South Africa predominantly framed in economic terms.

But the above excerpt not only represents the broader tone in contemporary South African education policy discussions, it also indicates the vested interests underpinning a relation of optimism towards education for most South Africans. As Berlant argues, neither slow death framed as ahistorical crisis nor sustained attachment to prevailing social institutions can be understood outside of class interests. While the status quo may be ordinary to the marginalised majority of South Africans, it is a cause of constant chatter and concern in the hegemonic middle-class minority. In the next section, I suggest that one of the mechanisms of both manufacturing ahistorical crisis, as well as sustaining attachment to the prevailing system amongst middleclass South Africans, is in what Evgeny Morozov (2013) terms "techno-solutionist" thinking.

\section{Techno-solutionism (and its terrifying utopias)}

Having described lifelong learning as ubiquitous in South African education policy, and suggested that a relation of cruel optimism explains why the fantasy of meaningful lifelong learning is rarely questioned, I now turn to a third aspect of South African education discourse which I suggest sustains this relation for those who experience a greater sense of agency in their lives, namely techno-solutionism.

In his book To Save Everything, Click Here, Morozov (2013) defines "solutionism" as

\footnotetext{
${ }^{6}$ For a discussion as to why it has not (yet) been officially finalised and implemented, see Black (2022).
} 
an unhealthy preoccupation with sexy, monumental and narrow-minded solutions ... to problems that are extremely complex, fluid and contentious. These are the kinds of problems that, on careful examination, do not have to be defined in the singular and all-encompassing ways that "solutionists" have defined them; what's [sic] contentious, then, is not their proposed solution but their very definition of the problem itself. ... solutionism presumes rather than investigates the problems that it is trying to solve ... How problems are composed matters every bit as much as how problems are resolved (ibid., p. 6).

Techno-solutionism involves combining this reductionism of complex social problems with whatever is deemed the latest technology, e.g. artificial intelligence, machine learning, 3D printing, personalised online learning environments, etc. Such approaches by necessity take an a-historic perspective, not only to elide the complexity of the issue in question, but to also posit the proposed solution as innovative and novel (an easy claim when prior efforts and interventions are ignored) and their originators as "disruptors" and heroes (cf. Leary 2018).

(A point of clarity: Morozov's position - which reflects my own - is not one of technophobia, but rather one he refers to as "digital heresy". What is being problematised here is not all and any use of technology in education or learning moments, but rather the prevailing discourses of efficiency, technicism and technology-as-a priorigood, external to social, political and economic context. The rapid, overly enthusiastic application of technology to complex social problems has, Morozov argues throughout his book, assumed a religious fervour, which frames dissent or critique as heretical.)

Like most ideologies, techno-solutionism proffers an imagined ideal, a "utopia" of sorts which allegedly only "moving fast and breaking things" can deliver. In South African education-related discussions amongst non-governmental organisations (NGOs), policymakers and civil society, such utopias are tacit yet common in fora, marketing materials and theories of change (for some examples, see GWF 2019; Ngnaoussi Elongue 2018; DGMT 2021; Western Cape Government 2019). The following "factional" tableau synthesises different aspects common in South African techno-solutionist utopian discourse:

Asemahle no longer has to walk 10 kilometres to school along a dusty road and cram into a tiny classroom with 60 classmates to wait for the teacher who is late. She now can reach for her iPad, charged by a solar battery bank she left outside her hut yesterday while she went to tend her grandmother's herd, and select her lessons for the day, in any order she wants, from the list presented. Although she lives in rural Cofimvaba, far from any urban centre, she knows she is on par with all the other Grade 6 learners around the country, with their lessons and curriculum synchronised by a central e-learning platform which monitors every child's progress, challenges, interests and curriculum coverage. She even beat her e-friend Noxolo (who lives in Cape Town) at maths games yesterday when they competed as to who could solve the fraction questions fastest. 
Gone are the days of a teacher who didn't know the curriculum. Gone are the days of scholar transport issues, of schools with no toilets, of waiting to move on with the lesson while the teacher dealt with classroom management, of sitting on the floor because there are no desks. Asemahle can now pursue her own learning at her own pace, from the safety of her grandmother's rural home, in any language she chooses. Education is now available to every child across the country to a quality previously unimagined. Technology has saved the day. ${ }^{7}$

While such fantasies may beguile some, they are impractical, reductionist, and - I suggest - also a little terrifying. They are impractical in given circumstances (techno-solutionism totally ignores the real material and social conditions of rural South African children, never mind existing technology's inability to cope with the agglutinative ${ }^{8}$ South African Indigenous languages); reductionist in imagining learning as just content delivery, at maximum pace, preferably gamified; and terrifying in their omission of human complexity, struggle and messiness (both real and ideal), as well as blithe non-engagement with unintended consequences. In such utopias, the humans become more robotic than the robots become human.

\section{The sustained manufacture of constant crisis ... and techno-solutionism as the remedy}

As Berlant stated earlier, the ordinary attrition of the subject might present to the external analyst as a crisis. I have argued elsewhere (Black 2020) that framing education ills as a crisis has an amnesiac effect, and Berlant too notices the temporal work of this framing: "the genre of crisis can distort something structural and ongoing within ordinariness into something that seems shocking and exceptional" (Berlant 2011, p. 7; emphasis added). This distortion provides fertile ground for ahistorical approaches like techno-solutionism. Berlant continues:

Without the ballast of ordinariness to distribute our analyses of "structure" as a suffusion of practices throughout the social, crisis rhetoric itself can assume a similar kind of inflation. Often when scholars and activists apprehend the phenomenon of slow death in long-term conditions of privation, they choose to misrepresent the duration and scale of the situation by calling a crisis that which is a fact of life and has been a defining fact of life for a given population that lives that crisis in ordinary time. Of course this deployment of crisis is often explicitly and intentionally a redefinitional tactic, an inflationary,

\footnotetext{
7 This text is a self-authored piece that is an amalgam/exemplar for the kinds of discourses about technology in education in South Africa that I witness frequently. The purpose is to synthesise the kinds of techno-solutionist narratives that are prevalent in local education civil society discussions, how "solutions" to education issues are imagined, and the kinds of problematic discourses perpetuated in doing so.

8 The term agglutinative is used in linguistics to refer to languages (e.g. isiXhosa) which use complex words with multiple elements rather than inflection (changes at the end of a word) or single elements to express concepts.
} 
distorting, or misdirecting gesture that aspires to make an environmental phenomenon appear suddenly as an event, because as a structural or predictable condition it has not engendered the kinds of historic action we associate with the heroic agency a crisis implicitly calls for (ibid., p. 101; emphases added).

This sharp observation between who refers to a situation as a crisis and who sees it as ordinary life aligns with the relation of education imaginaries in South Africa between those who the education system has systemically always failed, and those who once (now, or in the past) were actually offered a real promise of education.

Colin Griffin (2010) also uses the term "crisis" to describe the shift from welfarist policy approaches (such as those exemplified in the Faure report) to much-reduced state influence under neoliberalism. However, this sense of "loss" of a social democratic order in the Global North does not transfer to the Global South in contexts where such a benevolent modern policy apparatus - however flawed - has never been experienced; only a privileged minority of South Africans have experienced the state in truly welfarist terms. Berlant's observation quoted above suggests that a fabricated crisis necessitates "heroic agency" - a (self-)positioning by those who perceive the state to be "failing" as the actors who will save everyone. But most South Africans who are currently deprived of education opportunities - lifelong or otherwise - have never experienced such a relationship with the state, whose failure is part and parcel of the ordinariness of everyday struggle.

\section{Techno-solutionists to the rescue}

Techno-solutionism in education abounds, ${ }^{9}$ and South Africa is no exception. ${ }^{10}$ Teaching technology has long been an object of pedagogy, bolstered by human capital theory and supply-side interventionism that aspires to produce the required skills for a labour market supposedly hungry for "21st-century skills". Such curriculum reprioritisation began before democracy; the first inklings were in the report on the Provision of education in the Republic of South Africa compiled by the De Lange Commission in 1981 which was shelved by the Nationalist government at the time, but shaped the discourses of those who entered into the negotiated settlement with the ANC ten years later (Jacklin 2018; personal correspondence; HSRC 1981). By the mid-1990s, "technology" was an explicit subject even in basic schooling (Ankiewicz 1995), and has remained so since. In 2019, the Department of Basic Education announced the inclusion of more digital technology subjects in lower grades of compulsory schooling, including coding and robotics (BusinessTech 2019), and in 2020 (private) teacher-training centres were opened

\footnotetext{
9 There are thousands of examples online, but several can be found in an overview of "Top 10 TED Talks for EdTech" compiled by Matthew Lynch (2018).

${ }^{10}$ Techno-solutionist education imaginaries have been amplified and accelerated by the COVID-19 pandemic as public (state) schooling attempted to move online to accommodate public health restrictions. In South Africa, most public schools, which serve the marginalised majority, were unable to do this due to lack of material means both in the school and in students' homes.
} 
to prepare pedagogues in these 21st-century "Fourth industrial revolution" skills (iAfrica 2020).

Indicative of this discourse is the 2004 e-Education White Paper (DoE 2004), which envisions the technologically enhanced learning - and learner ${ }^{11}-$ of the future:

2.8 The challenge facing our education and training system is to create a learning culture that keeps pace with these changes, and equips people with the knowledge, skills, ideas and values needed for lifelong learning. Our education system must create graduates who use information effectively and keep abreast of technological advances.

2.17 The Department of Education believes that developments in ICTs [information and communications technologies] create access to learning opportunities, redress inequalities, improve the quality of learning and teaching, and deliver lifelong learning. ICTs can accommodate differences in learning styles and remove barriers to learning by providing expanded opportunities and individualised learning experiences (DoE 2004; emphases added).

But perhaps the most recent policy example of techno-solutionism, along with its entanglement with discourses of lifelong learning, is the Open Learning Policy Framework (OLPF) (DHET 2017). Peppered throughout the "draft" document (Black 2022) are references to how online learning, blended learning, open (public domain) education resources, micro-credentialism and many other education practices only viable at scale through digital technology will simultaneously offer lifelong learning opportunities that are humanising, oriented to social justice and instrumentalist towards economic improvement, all the while improving efficiency for the state in its provision (DHET 2017). As suggested previously, the seemingly contradictory discourses in such a document work in tandem to weave a fantasy for any reader, irrespective of their imagined ideal of education practice. The imagined future lifelong learner (cf. Jacklin 2018) envisioned in the OLPF is simultaneously economically upwardly mobile, concerned with issues of cultural justice, democratically engaged, self-driven, digitally literate, critically informed and entrepreneurial - in short, a "hero citizen" who has no need of welfare or the state - a utopian neoliberal subject. Such an object of fantasy simultaneously satisfies the desire for "hero agency" on the part of middle-class analysts who frame the present as a crisis, yet continues the out-of-reach ideals embedded in the ordinariness of most South Africans' everyday lived struggle.

The framing of education as crisis, then, seems perhaps a pastime of the hegemonic middle-class minority (including policymakers), who turn to techno-solutionism to sustain their own optimism in education as a route to improved national development. This framing, however, is ahistorical and decontextualised, and erases the prolonged experience of "non-education" that the vast majority of South Africans endure.

\footnotetext{
${ }_{11}$ The significance of the shift from "education" to "learning" and from "student" to "learner" is beyond the scope of this discussion - for further details, see Biesta (2010) and Griffin (2010).
} 


\section{Conclusion}

This article has sought to explore how the ideas of lifelong learning first outlined in UNESCO reports in 1972 and 1996 have been taken up and transformed in the post-democratic South African education policy milieu. Asking how South Africans continue to hope for education as a route out of varying social issues, I brought the lens of cruel optimism to bear on the question, to try and theorise a different relation that might offer explanatory power.

I have suggested three possible mechanisms at work that sustain South Africans' cruel optimism towards education despite non-delivery. The first is an analytical error that mistakes the ordinariness of suffering for the majority of South Africans as a crisis which demands agentic response. Noticing that not everyone considers the current moment one of crisis suggests that the relation of cruel optimism is a long-standing one that has not been challenged by a viable alternative. For the marginalised majority whose education does not fulfil their fantasies of a better life, the status quo has been centuries in the making by a relation to the state that has never truly expected beneficence. Lifelong learning relates to this status quo only in that it is synonymous with the constant attrition of the subject in everyday doing and being.

The second mechanism, I suggested, is in the suppression of any radical dissent by co-deploying discourses of instrumentalism and humanism as a binary, switching one for the other depending on the objections raised. The co-presence of both humanist and instrumentalist discourses in education policy serves as a bait-and-switch rationale for remaining invested in the project of education.

The third mechanism is the preservation of cruel optimism on the part of not the marginalised, but the vocal hegemonic middle-class minority who lack the levers of a capacitated welfare state (including, one might suggest, those within the apparatus of a withered neoliberal state who turn to market-based solutions instead) to induce widespread systemic change. This small group, impotent in the face of the complexity and scale of the issue, turn to techno-solutionism to sustain their own investment; confronted with the weight of history and the magnitude of the task at hand, optimistic fantasy turns to idealistic futurist imaginaries. Such theories of change tangle with discourses of lifelong learning in ways that warrant noticing in public policy documents, for example, in the draft OLPF.

What is offered here is not solutions on how to make South African's optimism in education less cruel, but a fresh description of prevailing discourses and their relations to hopes of a "good" (or even simply "better") life. In providing this, I hope to stimulate new lines of inquiry as to whether prevailing efforts are ever capable of bringing about the change they profess to seek. Only by denaturalising the work of these discourses, the fantasies they tacitly suggest and the social relations they undergird, can alternatives be dreamed or realised.

Acknowledgements This research was funded by a postdoctoral research fellowship at the Centre for Education Rights and Transformation, University of Johannesburg. 


\section{References}

Allais, S. (2020). Skills for industrialisation in sub-Saharan African countries: Why is systemic reform of technical and vocational systems so persistently unsuccessful? Journal of Vocational Education \& Training, [online first], 1-19. https://doi.org/10.1080/13636820.2020.1782455.

Ankiewicz, P. (1995). The planning of technology education for South African schools. International Journal of Technology and Design Education, 5(3), 245-254. https://doi.org/10.1007/BF007 69906

Ball, S. J. (1993). What is policy? Texts, trajectories and toolboxes. The Australian Journal of Education Studies, 13(2), 10-17. https://doi.org/10.1080/0159630930130203

Ball, S.J. (2015). What is policy? 21 years later: Reflections on the possibilities of policy research. Discourse: Studies in the cultural politics of education, 36(3), 306-313. https://doi.org/10.1080/01596 306.2015.1015279.

Berlant, L. (2011). Cruel optimism. Duke University Press.

Biesta, G. J. J. (2004). Education, accountability and the ethical demand: can the democratic potential of accountability be regained? Educational Theory, 54(3), 233-250. https://doi.org/10.1111/j.00132004.2004.00017.x

Biesta, G. J. J. (2006). What's the point of lifelong learning if lifelong learning has no point? On the democratic deficit of policies for lifelong learning. European Educational Research Journal, 5(3 \& 4), 169-180. https://doi.org/10.2304/eerj.2006.5.3.169

Biesta, G. J. J. (2010). Learner, student, speaker: Why it matters what we call those we teach. Educational Philosophy and Theory, 42(5-6), 540-552. https://doi.org/10.1111/j.1469-5812.2010.00684.x

Biesta, G. J. J. (2013). Interrupting the politics of learning. Power and Education, 5(1), 4-15. https://doi. org/10.2304/power.2013.5.1.4

Black, S. (2020). Education, Covid and care: Examining relations of "value" in schools during the 2020 pandemic. Presentation given 13 October at the Centre for Public Policy Research, King's College London. Retrieved 28 September 2021 from https://www.youtube.com/watch?v=uiZidlMnKcY.

Black, S. (2022). Marx's ghost in the shell: Troubling techno-solutionist utopias in post-secondary education and training policy imaginaries. Book chapter prepared for S. Vally \& E. Motala (Eds) [upcoming untitled peer-reviewed book compilation from the National Research Foundation South African Research Initiative's Chair in Community Adult and Worker Education]. Working paper retrieved 28 September 2021 from https://www.academia.edu/50168601/Marxs_Ghost_in_ the_Shell_troubling_technosolutionism_in_post_secondary_education_and_training_policy_imagi naries.

Bridle, J. (2019). New dark age: Technology and the end of the future. Verso Books.

BusinessTech (2019). South African schools will soon get these 8 new subjects - including coding. BusinessTech, 12 April [online article]. Retrieved 15 March 2021 from https://businesstech.co.za/news/ technology/310776/south-african-schools-will-soon-get-these-8-new-subjects-including-coding/.

Christie, P. (2008). Opening the doors of learning. Heinemann.

Delors, J., et al. (1996). Learning: The treasure within. Report to UNESCO of the International Commission on Education for the Twenty-first Century. Paris: United Nations Educational, Scientific and Cultural Organization (UNESCO).

DGMT (DG Murray Trust) (2021). A flying nation [online mission statement]. Claremont: DGMT. Retrieved 10 May 2021 from https://dgmt.co.za/our-strategy/.

DHET (Department of Higher Education and Training) (2013). White Paper on Post-school education and training: building an expanded, effective and integrated post-school system. Pretoria: DHET. Retrieved 17 September 2021 from https://www.dhet.gov.za/SiteAssets/Latest\%20News/White\% 20paper\%20for\%20post-school\%20education\%20and\%20training.pdf.

DHET (2017). Open learning policy framework for post-school education and training [draft]. Government Gazette, 40772(335). Retrieved 2 September 2021 from https://www.dhet.gov.za/sites/Polic yRepository/SitePages/Open\%20Learning.aspx.

DoE (Department of Education) (1995). White Paper on Education and training. [first Education White Paper]. Pretoria: Government Printing Works. Retrieved 2 September 2021 from: https://www.educa tion.gov.za/Resources/Legislation/WhitePapers.aspx

DoE (1997). White Paper on Higher education [Education White Paper 3]. Pretoria: Government Printing Works. Retrieved 2 September 2021 from: https://www.education.gov.za/Resources/Legislation/ WhitePapers.aspx 
DoE (1998). White Paper on Further education and training [Education White Paper 4]. Pretoria: Government Printing Works. Retrieved 2 September 2021 from: https:/www.education.gov.za/Resou rces/Legislation/WhitePapers.aspx

DoE (2004). White Paper on e-Education [Education White Paper 7]. Pretoria: Government Printing Works. Retrieved 2 September 2021 from: https://www.education.gov.za/Resources/Legislation/ WhitePapers.aspx

Elfert, M. (2015). UNESCO, the Faure report, the Delors report, and the political utopia of lifelong learning. European Journal of Education, 50(1), 88-100. https://doi.org/10.1111/ejed.12104

Elfert, M. (2018). UNESCO's utopia of lifelong learning: An intellectual history. Routledge.

Faure, E., et al. (1972). Learning to be: The world of education today and tomorrow. Paris/London: UNESCO/Harrap. Retrieved 2 September 2021 from https://unesdoc.unesco.org/ark:/48223/pf000 0001801.

Fiske, E. B., \& Ladd, H. F. (2004). Elusive equity: Education reform in post-apartheid South Africa. HSRC Press.

Friedrich, T., \& Lee, M. (2011). Technocratic and aesthetic-democratic being in UNESCO's lifelong learning policy discourse: An ideological analysis. Journal for the Philosophical Study of Education, 1, 153-172.

Griffin, C. (2010). Lifelong learning and social democracy. International Journal of Lifelong Education, 18(5), 329-342. https://doi.org/10.1080/026013799293586

GWF (Good Work Foundation) (2019). Under an African tree. GWF website, 25 April [online article]. Retrieved 10 May 2021 from https://www.goodworkfoundation.org/our-stories/under-an-afric an-tree/.

HSRC (Human Sciences Research Council) (1981). Provision of education in the Republic of South Africa. Report of the Main Committee of the HSRC Investigation into Education [the De Lange report]. Pretoria: HSRC.

iAfrica (2020). SA's First futuristic teacher training labs launched at Mancosa School of Education. iAfrica, 7 December [online news item]. Retrieved 2 February 2021 from https://iafrica.com/sas-firstfuturistic-teacher-training-labs-launched-at-mancosa-school-of-education/.

Jacklin, H. (2018). The imagined subject of schooling in the logic of policy. Journal of Educational Administration and History, 50(4), 256-269. https://doi.org/10.1080/00220620.2018.1453789

Leary, J. P. (2018). Keywords: The new language of capitalism. Haymarket Books.

Lee, M., \& Friedrich, T. (2011). Continuously affirmed, subtly accommodated, obviously missing and fallaciously critiqued: ideologies in UNESCO's lifelong learning policy. International Journal of Lifelong Education, 30(2), 151-169. https://doi.org/10.1080/02601370.2010.547619

Lynch, M. (2018). Top 10 TED talks for edtech. The Tech Advocate, 26 March [online article]. Retrieved 27 September 2021 from https://www.thetechedvocate.org/top-10-ted-talks-edtech/.

M\&G (Mail \& Guardian) (2020). Matric pass rates hide failures. Mail \& Guardian, 10 January [online article]. Retrieved 15 March 2021 from https://mg.co.za/article/2020-01-10-00-matric-pass-ratehides-failures/.

Morozov, E. (2013). To save everything, click here: The folly of technological solutionism. Public Affairs.

Ngnaoussi Elongue, C.C. (2018). Reasons why the gamification of the education system in Africa is important. eLearningIndustry, 6 May [online article]. Retrieved 10 May 2021 from https://elear ningindustry.com/gamification-of-the-education-system-in-africa-important-reasons.

RSA (Republic of South Africa) (2012). Our future - make it work. National Development Plan 2030. Pretoria: National Planning Commission of South Africa. Executive summary retrieved 2 September 2021 from https://www.gov.za/sites/default/files/Executive\%20Summary-NDP\%202030\%20-\% 200ur\%20future\%20-\%20make\%20it\%20work.pdf

Silbert, P. (2012). The imagined learner in neoliberal times: Constructions of the South African learning subject in education policy discourse and school practice. Unpublished doctoral thesis. University of Cape Town. Retrieved 2 September 2021 from https://open.uct.ac.za/handle/11427/14572.

Stats SA (Statistics South Africa) (2020). Vulnerability of youth in the South Africa labour market. Stats $S A$, 24 June [online news item]. Retrieved 15 March 2021 from http://www.statssa.gov.za/?p= 13379.

Union of South Africa (1953). Act 47 of 1953: The Bantu Education Act. Act to provide for the transfer of the administration and control of native education from the several provincial administrations to the Government of the Union, and for matters incidental thereto. Cape Town: Government of the Union of South Africa. Retrieved 28 September 2021 from https://www.sahistory.org.za/sites/default/files/ DC/leg19531009.028.020.047/leg19531009.028.020.047.pdf. 
Vally, S., \& Motala, E. (2014). Education, economy and society. UNISA Press.

Western Cape Government (2019). \#changethestory: The power of after school programmes. Western Cape Government website, 28 October [online news item]. Retrieved 10 May 2021 from https:// www.westerncape.gov.za/after-school-game-changer/news/changethestory-power-after-school-progr ammes.

Publisher's Note Springer Nature remains neutral with regard to jurisdictional claims in published maps and institutional affiliations.

Sara Black is a former high school maths teacher who now trains teachers and works in critical education sociology, with a focus on equity and justice in education policy. She is a Postdoctoral Fellow at the Centre for Education Rights and Transformation at the University of Johannesburg, and also lectures various postgraduate seminars including Education Policy, Education Leadership and Change, Advanced Research Design and Ethics in Education. A former software programmer, she also brings a critical social justice perspective to technology in education. 